\title{
Influences of Postharvest Storage and Processing Techniques on Antioxidant and Nutraceutical Properties of Rubus idaeus L.: A Mini-Review
}

\author{
Ermes Lo Piccolo ${ }^{1}$, Leani Martìnez Garcìa ${ }^{2}$, Marco Landi ${ }^{1,3}{ }^{\mathbb{D}}$, Lucia Guidi $1,3, * \mathbb{C}$, \\ Rossano Massai ${ }^{1,3}$ (D) and Damiano Remorini ${ }^{1,3}(\mathbb{D}$ \\ 1 Department of Agriculture, Food \& Environment, University of Pisa, Via del Borghetto 80, 56124 Pisa, Italy; \\ ermes.lopiccolo@agr.unipi.it (E.L.P.); marco.landi@unipi.it (M.L.); rossano.massai@unipi.it (R.M.); \\ damiano.remorini@unipi.it (D.R.) \\ 2 Grupo Tecnico Nacional de Plantas Medicinales de la Asosiacion Cubana de Tecnicos Agricolas \\ Agroforestales (ACTAF), Calle 98, Esquina 7ma, Playa, La Habana 11300, Cuba; leanimartinez93@gmail.com \\ 3 Interdepartmental Research Center Nutrafood "Nutraceuticals and Food for Health", University of Pisa, \\ Via del Borghetto 80, 56124 Pisa, Italy \\ * Correspondence: lucia.guidi@unipi.it; Tel.: +39-50-2216613; Fax: +39-50-2216087
}

Received: 3 November 2020; Accepted: 14 December 2020; Published: 16 December 2020

\begin{abstract}
The growth of agricultural mechanization has promoted an increase in raspberry production, and for this reason, the best postharvest storage and processing techniques capable of maintaining the health beneficial properties of these perishable berry fruits have been widely studied. Indeed, raspberries are a rich source of bioactive chemical compounds (e.g., ellagitannins, anthocyanins, and ascorbic acid), but these can be altered by postharvest storage and processing techniques before consumption. Although there are clear differences in storage times and techniques, the content of bioactive chemical compounds is relatively stable with some minor changes in ascorbic acid or anthocyanin content during cold $\left(5^{\circ} \mathrm{C}\right)$ or frozen storage. In the literature, processing techniques such as juicing or drying have negatively affected the content of bioactive chemical compounds. Among drying techniques, hot air (oven) drying is the process that alters the content of bioactive chemical compounds the most. For this reason, new drying technologies such as microwave and heat pumps have been developed. These novel techniques are more successful in retaining bioactive chemical compounds with respect to conventional hot air drying. This mini-review surveys recent literature concerning the effects of postharvest storage and processing techniques on raspberry bioactive chemical compound content.
\end{abstract}

Keywords: anthocyanin; ascorbic acid; drying method; phenol; phytochemical; raspberry

\section{Introduction}

Currently, interest towards fruits and vegetables has been continually increasing due to the awareness that they are a primary source of bioactive, health-beneficial compounds. Raspberry (Rubus idaeus L.) belongs to the Rosaceae family and represents one of the oldest fruits that has been used for millennia for human nutrition and as a folk medicine [1]. Raspberries are a rich source of bioactive chemical compounds (e.g., ellagitannins, anthocyanins, ascorbic acid) with a high antioxidant capacity, useful for the prevention of chronic human diseases [2,3]. Indeed, there is a growing interest by consumers that the consumption of these fruit can exert positive effects on human health $[2,4,5]$ due to their nutritional and nutraceutical content (Figure 1). Fresh raspberries have low calories, about 50 $\mathrm{kcal} 100 \mathrm{~g}^{-1}$, and together with their high content in dietary fibers make them a snack that has a satiating effect [2]. The most representative bioactive chemical compounds found in red raspberry fruit belong 
to the polyphenol class (normally total phenolic content ranges from $\sim 100$ to $600 \mathrm{mg} 100 \mathrm{~g}^{-1}[4,6,7]$ ). In particular, ellagitannins, such as lambertianin $\mathrm{C}$ and sanguiin $\mathrm{H}-6$, and flavonoids, principally anthocyanins, are the major polyphenols found in raspberry (Figure 1) [6-10]. According to recent studies, anthocyanins in raspberries are mainly represented $(>90 \%)$ by cyanidin-glycosides (cyanidin 3-O-glucoside, cyanidin 3-O-rutinoside, cyanidin 3-glucosylrutinoside and cyanidin 3-sophoroside) and pelargonidin glycosides (pelargonidin 3-glucoside) [7,9]. Another important antioxidant in raspberry is ascorbic acid, which is contained in this fruit at a lower concentration as compared to orange and kiwifruit [11,12].

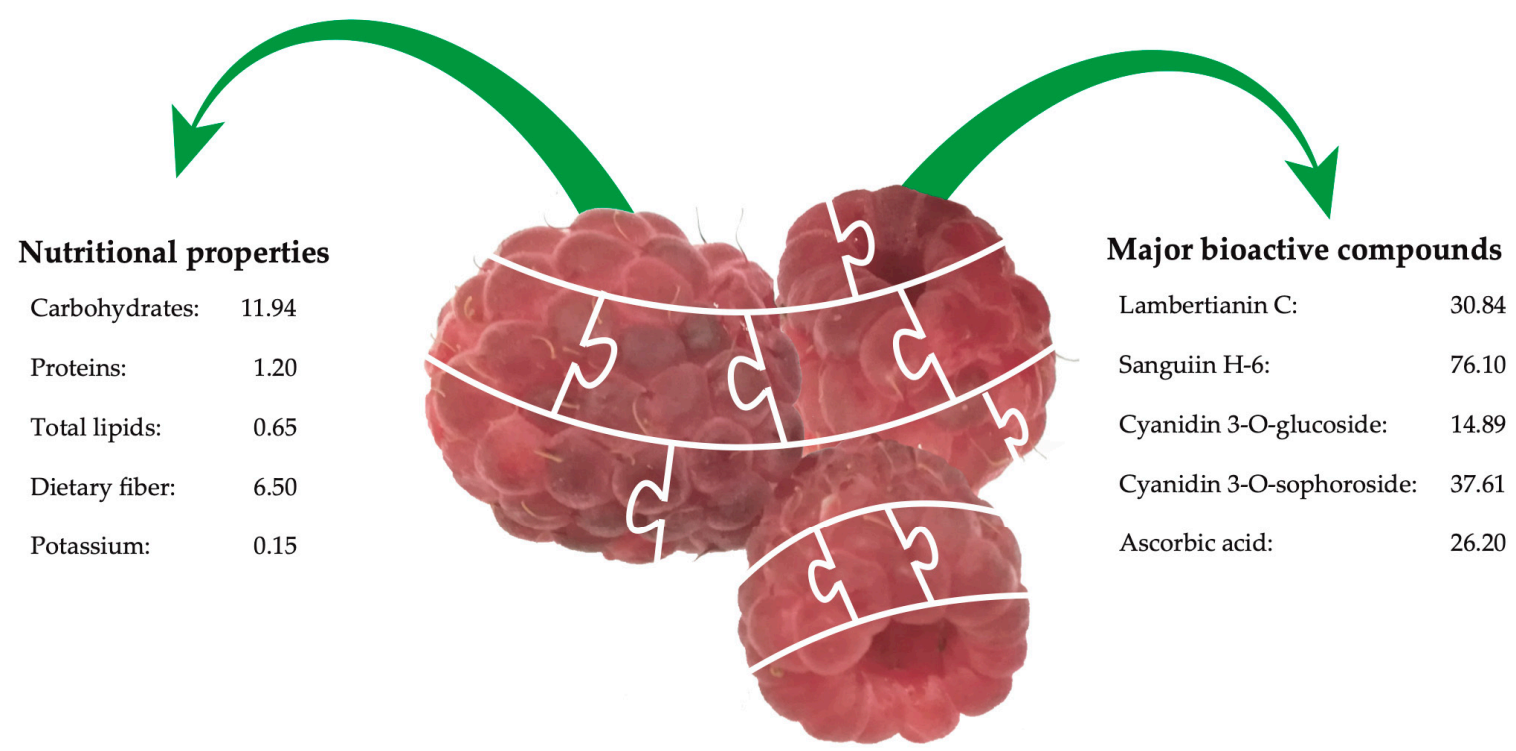

Figure 1. Nutritional (g $100 \mathrm{~g}^{-1}$ ) and major bioactive compounds ( $\mathrm{mg} 100 \mathrm{~g}^{-1}$ ) in raw red raspberry fruits. Values were obtained from 'Phenol Explorer Database' and the literature [2,10].

The first information about raspberry cultivation comes from the Romans in the 4th century. In the last 20 years, the production of raspberry has been consistently enhanced, with a yield increase of $106 \%$ [13]. The largest production among countries is the Russian Federation with about $148 \mathrm{t} \mathrm{year}^{-1}$ (averaged data from the previous two decades), followed by Serbia $\left(88 \mathrm{t} \mathrm{year}^{-1}\right)$, Poland $\left(83 \mathrm{t}\right.$ year $\left.{ }^{-1}\right)$, and the United States $\left(80 \mathrm{t} \mathrm{year}^{-1}\right.$ ). However, in recent years, Mexico has become a major raspberry producer, with about $60 \mathrm{t} \mathrm{year}^{-1}$ (averaged from the last decade) [13]. The increase in the production of raspberry is likely attributable to a combination of different factors, such as globalization of berry markets, agricultural mechanization, and, last but not least, the increased interest of consumers for healthy food products.

However, raspberry is a very perishable soft fruit, and the increasing quantities produced set a double challenge for the food industry to develop processing techniques that utilize any overproduction (which results in wasted food) and preserve the fruit nutritional and nutraceutical qualities [14]. The use of postharvest storage techniques such as cold storage, a controlled atmosphere, and frozen storage can effectively prolong the postharvest quality of raspberry, making them suitable for their global commercialization [15-17]. Moreover, raspberry berries can be dry processed in order to not only preserve their nutritional properties, but also to make new foods with highly health-beneficial qualities for human consumption. In previous studies, a number of different technologies have been utilised for raspberry dehydration: freeze-drying, hot air-drying, microwave-drying, and a combination, and each technique has shown positive and negative effects [18-21]. Juice production is another industrial technique for processing fresh raspberry fruit and to extend their availability in the global market. Fruit juices are labelled as functional foods and may be introduced into the diet to increase the daily intake of functional metabolites [22]. However, the use of the abovementioned postharvest storage 
and processing techniques (which work with different parameters, e.g., temperatures, processing time) could cause potential variation at physical, biological and biochemical levels, which in turn may alter fruit bioactive chemical compound content, affecting the nutraceutical properties that have become appreciated by consumers [23-25]. For example, the red color of raspberries can be significantly affected by these processing techniques, since the reddish color is due to the presence of flavonoids, i.e., anthocyanins, which can be very sensitive to thermal processing techniques [26,27]. The human eye is attracted by red coloration, and, in particular, a high chromatic reddish coloration of fruit is perceived as a positive characteristic associated with fruit maturity stage, indirectly providing information about the fruit sweetness and quality [28-30]. Therefore, studies of new storage and processing/transformation technologies aimed at reducing negative changes in the content of bioactive chemical compounds of raspberry fruit represent this continuous challenge for researchers and the food industry. Moreover, as a large part of raspberry production is industrially processed, the detection of changes of the most representative bioactive compounds in raspberry fruits caused by transformation processes could provide useful information for estimating the health-related properties of a specific end product [31]. Therefore, the aim of this review is: (i) to describe the main bioactive chemical compounds contained in raspberries, highlighting their potential health benefits derived from their consumption; (ii) to report a survey of the most recent literature concerning the possible influences of postharvest storage and processing techniques (juicing and drying) on raspberry bioactive chemical compound content; and, (iii) to present novel data about the effects of a recent drying technique (heat pump) on bioactive chemical compounds of raspberry fruits.

\section{Postharvest Storage}

\subsection{Cold/Modified Atmosphere Storage}

After harvest, fresh raspberries are stored before undergoing further processing. This postharvest storage is necessary because raspberry fruits have a short postharvest life due to their high respiration rate and loss of firmness [32]. Progressive loss of firmness is associated with a loss of skin strength that leads to fruit softening, which in turn favors the onset of molds with loss of the product [33,34]. Studies conducted on the relationship between normal cold storage conditions and shelf-life of red raspberry fruits have established that raspberries can be successfully stored near 1 to $2{ }^{\circ} \mathrm{C}$ up to about 10 days, though these conditions do not reflect a realistic storage (usually 4 to $5{ }^{\circ} \mathrm{C}$ ) $[15,35,36]$. In definition, it is difficult to preserve these small fruits, and for this reason, it is important to describe storage methods and technologies that can preserve not only the product, but also their nutritional and healthful properties.

It has been reported that the use of different storage temperatures affects the content of bioactive compounds (e.g., phenolics and ascorbic acid; Table 1) in different ways. The total phenolic content as well as the antioxidant capacity are relatively stable throughout storage by using low temperatures $\left(1-5^{\circ} \mathrm{C}\right)$ [35-37], even though a slight decrease in total phenolic content (with storage temperatures of $1^{\circ} \mathrm{C}$ ) was reported by Giuffrè et al. [35]. On the other hand, Mullen et al. [37], by simulating a realistic storage condition $\left(4^{\circ} \mathrm{C}\right)$, found that ellagitannin levels increased, but no changes in the total antioxidant capacity were detected. 
Table 1. Changes in content of some bioactive compounds and antioxidant capacity in fresh raspberry fruit by different raspberry storage conditions. $(\uparrow)$ : increased contents; $(\downarrow)$ : decreased contents; $(=)$ : unchanged contents.

\begin{tabular}{ccc}
\hline Storage Conditions & $\begin{array}{c}\text { Influence on Antioxidant } \\
\text { Compounds and Activity }\end{array}$ & References \\
\hline \multirow{2}{*}{ Cold storage $1-2{ }^{\circ} \mathrm{C}$} & Phenols $(\uparrow \downarrow)$ & {$[35,38]$} \\
& Anthocyanins $(\uparrow)$ & {$[15,35,38,39]$} \\
& Ellagic acid $(=)$ & {$[38]$} \\
& Ascorbic acid $(=)$ & {$[15,35,38]$} \\
Cold storage $\sim 5{ }^{\circ} \mathrm{C}$ & Phioxidant capacity $(=)$ & {$[35]$} \\
& Anthocyanins $(\uparrow)$ & {$[40,41]$} \\
& Ellagitannins $(\uparrow)$ & {$[40,41]$} \\
& Ascorbic acid $(\downarrow)$ & {$[37]$} \\
Controlled atmosphere & Antioxidant capacity $(=\uparrow)$ & {$[37,40,41]$} \\
& Anthocyanins $(=)$ & {$[15]$} \\
& Ascorbic acid $(=)$ & {$[15,42]$} \\
\hline Frozen storage $\sim 1$ year & Phenols $(=\uparrow)$ & {$[43-45]$} \\
& Anthocyanins $(=\downarrow)$ & {$[45,46]$} \\
& Ellagic acid $(\downarrow)$ & {$[43,47]$} \\
& Ascorbic acid $(\downarrow)$ & {$[43,45]$} \\
& Antioxidant capacity $(=)$ & {$[43,44]$} \\
\hline
\end{tabular}

Among different bioactive compounds in raspberries, anthocyanins are important for the organoleptic characteristics of these small fruits. Some have reported that total anthocyanin content increases during storage, independently of storage temperatures $[15,35,39,40]$, but others found a decrease in total monomeric anthocyanins when raspberries were stored at $3{ }^{\circ} \mathrm{C}$ [36]. There have been contrasting results on the effect of temperature storage on phenolics in raspberry. It is important to note that, during cold storage, fruit weight loss can influence the correct estimation of bioactive compounds on a fresh weight basis and attention should be paid to this when storage effects on bioactive chemical compound content are evaluated [32]. In addition, it has been reported that during cold storage, a decrease in organic acid content can occur and this makes the carbon skeleton for the synthesis of polyphenols available [48].

Another important bioactive compound in raspberry is ascorbic acid, and it has been reported that its content in fresh raspberries stored at 1 to $2{ }^{\circ} \mathrm{C}$ was relatively stable $[15,35,38]$. However, its content is strictly related to the temperature used during storage. Indeed, at relatively higher temperatures (around $5{ }^{\circ} \mathrm{C}$ ), ascorbic acid content slightly decreased [37,40], most likely attributed to the greater rate of oxidation of this compound that can occur at this temperature (Table 1).

Modification of storage atmosphere (at low temperatures close to 0 to $2{ }^{\circ} \mathrm{C}$ ) while also changing $\mathrm{O}_{2}$ and $\mathrm{CO}_{2}$ concentrations (controlled atmospheres (CA)) are widely used to extend the fruit shelf-life, significantly suppressing rotting $[15,49,50]$. Although plenty of information is available on the effect of CA storage on fruit shelf-life for some berry fruits (e.g., blueberry and strawberry), the literature on raspberry CA storage is scarce, and the correlation between CA and red raspberry nutraceutical traits are almost non-existent. Previous studies conducted on CA effects on raspberry shelf-life confirmed an extension of berry storability ( $>50 \%$ ), delaying fruit decay by using 10 to $35 \% \mathrm{O}_{2}$ and 15 to $45 \%$ $\mathrm{CO}_{2}[15,16,42,51]$. Anthocyanins and ascorbic acid content were unchanged after CA storage (Table 1), indicating that $\mathrm{CA}$ is effective in maintaining nutraceutical value for longer periods than normal storage $[15,42]$. Better results in the retention of bioactive compounds in raspberry have been related to lower $\mathrm{O}_{2}$ concentrations, which reduce the oxidative reactions that typically can occur during fruit storage. 


\subsection{Frozen Storage}

Certainly, lower temperatures than those described above, i.e., frozen storage, represent a way to store red raspberries for longer periods, making them available all year round. Usually, for frozen storage, temperatures around $-20^{\circ} \mathrm{C}$ have been used. De Ancos et al. [43] found that total phenolic content and total antioxidant capacity remained substantially unchanged after 12 months of frozen storage even though ellagic acid and ascorbic acid significantly decreased (Table 1). The decrease in free ellagic acid detected during frozen storage in red raspberry could be related to the capacity of this acid to act as a metal chelating agent with $\mathrm{Mg}^{+2}$ and $\mathrm{Ca}^{+2}$ and/or to the action of polyphenol oxidase (PPO) linked to the cell wall, which is most likely degraded by ice crystals $[43,47,52]$ (Table 1$)$. Others $[44,45]$ have reported that after 12 months of frozen storage the total phenolic content increased in raspberry fruit. The authors suggested that the increase in phenolics was attributable to the degradation of cell structures by ice crystals, thereby making those compounds more easily available during extraction. Total anthocyanin content decreased in some cultivars after frozen storage $[45,46]$ while it remained unchanged in others [46] (Table 1), indicating differing effects of frozen temperature by genotype and the type of chemical structure of the anthocyanin contained in it. For example, cyanidin 3-glucoside is much more prone to degradation during frozen storage than other cyanidin-based derivatives, especially diglycosidic anthocyanins $[45,46]$. More generally, it has been reported that cyanidin 3 -O-glucoside is one of the most reactive anthocyanins during processing [53,54].

The loss in anthocyanin content due to oxidation and/or condensation reactions with other phenolic compounds did not interfere with antioxidant activity, as that is generally maintained or increased following frozen storage [55]. This can be attributed to the interference or association of the phenolic compounds and anthocyanin degradation products.

\section{Processing Techniques}

\subsection{Juicing}

Raspberry juice is a commercially important product, consumed pure or more usually blended with other fruit juices to enhance their color or the flavor. Red-colored juices are very appreciated by consumers; indeed, a new market-segment related to red-colored fruits and their processed products is increasing thanks to consumer association of red-colored fruit to high antioxidant properties $[22,56,57]$. Fruit juice is the result of a complex industrial process in which thawed fruit go through a series of operations (e.g., crushing, pressing, enzymatic treatment, thermal/non-thermal treatments, clarification/filtration) in order to obtain the final product [24]. All of these processes decrease the content of the antioxidant compounds in the juice with respect to their fresh fruit levels. Losses of bioactive chemical compounds during juice processing should be minimized to retain beneficial health effects. However, literature on this topic is scarce for raspberries, when compared to other berries such as blackberries [53,58,59] (Table 2). An interesting experiment conducted by Sojka et al. [58] with red raspberry juice showed that about $68 \%$ of total anthocyanins, $12 \%$ of ellagitannins, $31 \%$ of flavonols, and $17 \%$ of flavanols were retained in fruit juice as compared to the fresh material. This indicates that the industrial processes carried out to obtain raspberry juice resulted in a large decrease in the bioactive chemical compounds with different effects based on chemical structure. Generally, it is well known that the high temperatures used to obtain juice negatively affect nutritive quality by destroying essential nutrients and biologically active "non-essential" components such as polyphenols $[24,53]$. For this reason, novel technologies that can preserve nutrient quality but also food safety are desirable. For example, high hydrostatic pressure (HHP) is a relatively new technology that can be utilized instead of thermal processes such as pasteurization. However, there are no studies on the use of this technology on raspberry juice production, but it is well known that HHP allows high retention of bioactive compounds of juice $[24,60]$. 
Table 2. Changes in content of selected bioactive compounds and antioxidant capacity by different processing techniques of fresh raspberry fruit. $(\uparrow)$ : increased content; $(\downarrow)$ : decreased content; $(=)$ : unchanged content.

\begin{tabular}{|c|c|c|c|}
\hline $\begin{array}{l}\text { Processing } \\
\text { Techniques }\end{array}$ & Conditions & $\begin{array}{l}\text { Influence on Antioxidant } \\
\text { Compounds and Activity }\end{array}$ & References \\
\hline Juicing & $\begin{array}{l}\text { Enzymatic treatment } \\
\text { Thermal treatment }\end{array}$ & $\begin{array}{c}\text { Phenols }(\downarrow) \\
\text { Anthocyanins }(=\downarrow) \\
\text { Ellagic acid }(\downarrow) \\
\text { Ellagitannins }(\downarrow) \\
\text { Antioxidant capacity }(=\downarrow)\end{array}$ & $\begin{array}{c}{[58,59]} \\
{[53,58,59]} \\
{[58]} \\
{[58]} \\
{[59]}\end{array}$ \\
\hline Freeze-drying & $\sim-50^{\circ} \mathrm{C}$ & $\begin{array}{c}\text { Phenols }(=\downarrow \uparrow) \\
\text { Anthocyanins }(=\downarrow \uparrow) \\
\text { Ellagic acid }(\downarrow) \\
\text { Ascorbic acid }(=\downarrow) \\
\text { Antioxidant capacity }(=\downarrow)\end{array}$ & $\begin{array}{c}{[18,19,21,61,62]} \\
{[18,19,21,62]} \\
{[20]} \\
{[21,62]} \\
{[18,19,62]}\end{array}$ \\
\hline Hot air drying & $\sim 65^{\circ} \mathrm{C}$ & $\begin{array}{c}\text { Phenols }(\downarrow) \\
\text { Anthocyanins }(\downarrow) \\
\text { Ellagic acid }(\downarrow) \\
\text { Ascorbic acid }(\downarrow) \\
\text { Antioxidant capacity }(\downarrow)\end{array}$ & $\begin{array}{c}{[19,20,62]} \\
{[19-21,59]} \\
{[20]} \\
{[21,62]} \\
{[19,20]}\end{array}$ \\
\hline \multirow{6}{*}{ Microwave } & Microwave & $\begin{array}{c}\text { Phenols }(\downarrow) \\
\text { Antioxidant capacity }(\downarrow)\end{array}$ & $\begin{array}{l}{[63,64]} \\
{[63,64]}\end{array}$ \\
\hline & Microwave/hot air & $\begin{array}{c}\text { Phenols }(\downarrow) \\
\text { Anthocyanins }(\downarrow) \\
\text { Antioxidant capacity }(\downarrow)\end{array}$ & $\begin{array}{c}20,63,64] \\
{[20]} \\
{[20,63,64]}\end{array}$ \\
\hline & Microwave/IR & $\begin{array}{c}\text { Phenols }(\downarrow) \\
\text { Anthocyanins }(\downarrow) \\
\text { Antioxidant capacity }(\downarrow)\end{array}$ & $\begin{array}{l}{[19]} \\
{[19]} \\
{[19]}\end{array}$ \\
\hline & \multirow{3}{*}{ Microwave/vacuum } & Phenols $(\downarrow)$ & [20] \\
\hline & & Anthocyanins $(\downarrow)$ & {$[20]$} \\
\hline & & Antioxidant capacity $(\downarrow)$ & [20] \\
\hline Heat pump & $30-35^{\circ} \mathrm{C}$ & $\begin{array}{c}\text { Phenols }(\downarrow) \\
\text { Anthocyanins }(\downarrow) \\
\text { Ascorbic acid }(\downarrow) \\
\text { Antioxidant capacity }(\downarrow)\end{array}$ & $\begin{array}{l}\text { [our results, see } \\
\text { Table 3] }\end{array}$ \\
\hline
\end{tabular}

\subsection{Freeze-Drying}

Freeze-drying is considered the most effective technique for preserving food quality $[65,66]$. The fruit samples are dried under vacuum at low temperatures (about $-50{ }^{\circ} \mathrm{C}$ ) maintaining bioactive chemical compound content almost unaltered from fresh fruit in comparison to other drying techniques [65,66]. Sablani et al. [18] confirmed the effectiveness of freeze-drying in retaining bioactive chemical compounds in freeze-dried raspberry tissue, in some cases improving phenolic content compared to fresh berries (Table 2). In contrast, some authors have shown different results [19-21,61], raising doubts about its efficacy in not altering the content of bioactive compounds of raspberry fruit [21]. For example, Stamenkovic et al. [62] reported a decrease in total phenolic content, anthocyanin levels, and radical scavenging capacity after freeze drying, while ascorbic acid content remained unchanged likely due to the very low temperature and the limited oxygen availability during the drying process (Table 2). Opposite effects have also been found with other fruit and vegetable materials [67]. In general, there is no clear explanation for the reason(s) for which bioactive compound levels decrease, increase, or remain unchanged during freeze-drying since antioxidants are very sensitive to light, oxygen, temperature, and $\mathrm{pH}$ and can also be degraded by enzymes [67-69]. However, among drying methods, freeze drying is currently the most effective in preserving the content of bioactive compounds, 
but its biggest disadvantage is the high cost due to length of time and energy-costs, making it difficult to use in the food industry [67].

\subsection{Hot Air-Drying}

Hot air-drying technology represents the most economical and common processing technology for drying food-including raspberries-despite its high temperatures and long drying times. During the process, food samples are exposed to hot air and the presence of oxygen. This combination of oxygen and higher temperatures-even if for a short time-results in high losses of bioactive compounds [23,62]. Therefore, it is necessary to find a reasonable compromise between temperatures and duration time for the entire drying process to make it a viable option.

Many studies of the hot air-drying technique conducted with raspberry (Table 2) have used temperatures around $65{ }^{\circ} \mathrm{C}$ to assess the effects of this method on bioactive chemical compound content $[19,20,23,59,62]$. It has been established that high temperatures during hot air-drying negatively affect the ascorbic acid content [69], with losses of around 90\% in raspberry (dried vs. fresh fruits) [21,62] (Table 2). However, the moisture of the products is involved in the negative influence on ascorbic acid content during the drying process [70].

It has also been observed that hot air-drying decreased the fruit phenolic content as compared to values for fresh raspberry fruit $[19,20,62]$. This phenomenon is likely due to thermal degradation of the phenolic compounds during the hot air-drying process [19,62], and not only negatively affects the health-related benefits of the final product but also affects the appearance by changing the colour (Table 2). Indeed, the products of anthocyanin thermal degradation are colourless carbinol and chalcone that cause a colour loss to the dried fruit [26,27] (Table 2).

Some authors, comparing different drying techniques, have detected a higher content in some phenols in raspberry fruits when air-dried rather than freeze-dried [19,23,62], whereas anthocyanins have always been found to decrease with air drying rather than freeze-drying samples. Nevertheless, the increase in total phenolic content in air-dried fruit compared to freeze-dried fruit was most likely linked to the release of bound phenol groups or more destruction of the tissue by higher temperatures allowing greater extraction of phenolic molecules $[19,23]$. Undoubtedly, the low costs of this technique are significant when compared to more sophisticated technologies (e.g., freeze-drying), but the hot air-drying approach has considerable limitations in preserving the nutraceutical properties of raspberry.

\subsection{Microwave-Drying}

Microwave-drying technology uses the microwaves to directly generate heat inside the fruit due to the microwave-promoted molecular oscillation. This results in decreasing the processing time [71], thereby increasing bioactive compound retention as compared to conventional hot air-drying [20]. For raspberries, microwave drying is usually combined with additional treatments such as hot air, infra-red radiation (IR), and vacuum-drying $[19,20,63]$ (Table 2), in an attempt to increase the retention of bioactive compounds. Microwave-dried raspberries retained a high antioxidant capacity compared to microwave/hot air-dried raspberries (about $40 \%$ vs. $20 \%$, respectively), if compared to fresh raspberry fruits [63]. Similar results were obtained by Mejia-Meza et al. [20] and Si et al. [19], in which microwave/vacuum-drying or microwave/IR-treated raspberry samples showed a higher anthocyanin level and a greater total antioxidant capacity than samples treated by microwave/hot air-drying or hot air-drying processing. The greatest reduction in antioxidant capacity occurred when hot air-drying was used, and this decrease is potentially related to the degradation of bioactive chemical compounds at high temperatures. It could be argued that even in the IR treatment, the temperatures reached inside the drying chamber were around $70^{\circ} \mathrm{C}$, but it should be taken into account that the drying time also plays a key role in the preservation of bioactive chemical compound levels. Indeed the IR treatment lasted $60 \mathrm{~min}$ whereas hot air-drying requires many more hours [19]. Therefore, microwave-drying (characterized by reduced time and temperatures) results are more advantageous for bioactive compound retention than conventional hot air-drying. Compared with freeze-drying, 
all microwave drying systems have shown high retention of total phenols, although lower levels of anthocyanins were usually detected $[19,20]$. The reduced drying time and costs of microwave drying processes may provide advantages when compared to freeze drying [20].

\subsection{Heat Pump-Drying}

A heat pump dehumidifier drying system (HP) is more environmentally friendly than conventional hot air-drying methods thanks to its high energy efficiency. This also results in lower production costs [72]. The process is relatively simple; low moisture air is blown into the drying chamber to absorb moisture from the fruit sample. The air moisture is eliminated through condensation at a low temperature $\left(-20\right.$ to $15{ }^{\circ} \mathrm{C}$ ) by the dehumidifier and then heated (at $30-35^{\circ} \mathrm{C}$ ) to start a new cycle (Table 2). The lower drying temperatures compared to conventional hot air-drying systems potentially provide a better quality of the dried product, which retains high concentrations of phenolics and ascorbic acid [73]. However, there is a lack of knowledge about the effects of heat pump-drying on the bioactive compounds of raspberry fruit, raising the need to understand whether this new process can be a valid substitute for conventional methods. For this purpose, an experiment was conducted in our laboratory to test the effects of heat pump-drying treatment on total phenolics, total anthocyanins, and ascorbic acid content and total antioxidant capacity in comparison to hot air-drying treatment at $65^{\circ} \mathrm{C}$ on an ecotype of raspberry grown in Garfagnana (Tuscany), Italy, (Figure 2; Table 3). The total phenolic content decreased significantly after the dehydration with both hot air and heat pump treatments as compared with values recorded in fresh material (Tables 2 and 3). However, the decrease in phenolics caused by both drying treatments could be ascribed to two distinct causes. During the conventional hot air process, phenols can be thermally degraded as reported and explained in previous studies $[19,20,74]$. On the other hand, in the heat pump-drying treatment (characterized by lower temperatures), the reduction of phenolics is more likely attributable to enzymatic degradation (e.g., by PPO), since 30 to $35^{\circ} \mathrm{C}$ is closer to the optimum temperatures for PPO activity $[75,76]$. A similar process may also explain the effect on anthocyanin content; however, anthocyanins were retained more with the heat pump than the hot air treatment (87 and $66 \%$ of retention, respectively).

Table 3. Total phenolic (TP), total anthocyanin (TA), ascorbic acid (AA) content, and total antioxidant capacity (TAC) in fresh raspberry fruit grown in Garfagnana (Italy), and after conventionally hot air-drying $\left(65^{\circ} \mathrm{C}\right.$ for $\left.20 \mathrm{~h}\right)$ and heat pump-drying $\left(35^{\circ} \mathrm{C}\right.$ for $\left.2 \mathrm{~d}\right)$. Each value is the mean of three replicates \pm standard deviation.

\begin{tabular}{|c|c|c|c|c|}
\hline & Units & Fresh & Hot Air $65^{\circ} \mathrm{C}$ & Heat Pump \\
\hline $\mathrm{TP}^{\mathrm{z}}$ & mg GA $A^{y}$ eq. $g^{-1} d w$ & $152.36 \pm 5.13 a^{x}$ & $123.31 \pm 6.00 \mathrm{~b}$ & $119.27 \pm 12.28 \mathrm{~b}$ \\
\hline $\mathrm{TA}$ & mg Cya glu. eq. $\mathrm{g}^{-1} \mathrm{dw}$ & $1.18 \pm 0.03 \mathrm{a}$ & $0.78 \pm 0.07 c$ & $1.03 \pm 0.09 b$ \\
\hline AA & $\mathrm{mg} \mathrm{g}^{-1} \mathrm{dw}^{-}$ & $2.01 \pm 0.13 a$ & $1.01 \pm 0.08 c$ & $1.20 \pm 0.05 b$ \\
\hline TAC & $\mathrm{mg}$ Trolox eq. $\mathrm{g}^{-1} \mathrm{dw}$ & $83.44 \pm 3.45 \mathrm{a}$ & $32.20 \pm 1.76 b$ & $31.38 \pm 4.06 \mathrm{~b}$ \\
\hline
\end{tabular}

\footnotetext{
${ }^{\mathrm{z}}$ TA was analyzed as reported in Lo Piccolo et al. [77]; TP, AA and TAC were analyzed as reported in Ceccanti et al. [78]. ${ }^{y}$ GA: gallic acid; Cya glu: cyanidin-glucoside. ${ }^{x}$ Within each row, means flanked by the same letter are not significantly different after a one-way ANOVA test with postharvest treatment as source of variability following a least significant difference (LSD) test $(P=0.05)$.
}

Our results also showed that ascorbic acid content decreased with both treatments (50 and $40 \%$ for HP and hot air-drying, respectively), although there was a difference in temperatures utilized in the two methods. Notably, though there were differences among treatments in the retention of bioactive compounds, the total antioxidant capacity decreased considerably in both treatments to about $60 \%$ of that detected in fresh fruit. The similar values in total antioxidant capacity between hot air and heat pump dried samples could be explained by the similar contents in total phenolics in both treatments. Indeed, Beekweelder et al. [79] reported that ellagitannins contributed more than $50 \%$ to the total antioxidant activity, so this may be the reason why total antioxidant activity was similar for the hot air 
and heat pump dried samples, even though ascorbic acid and anthocyanin contents were higher in heat pump dried samples.

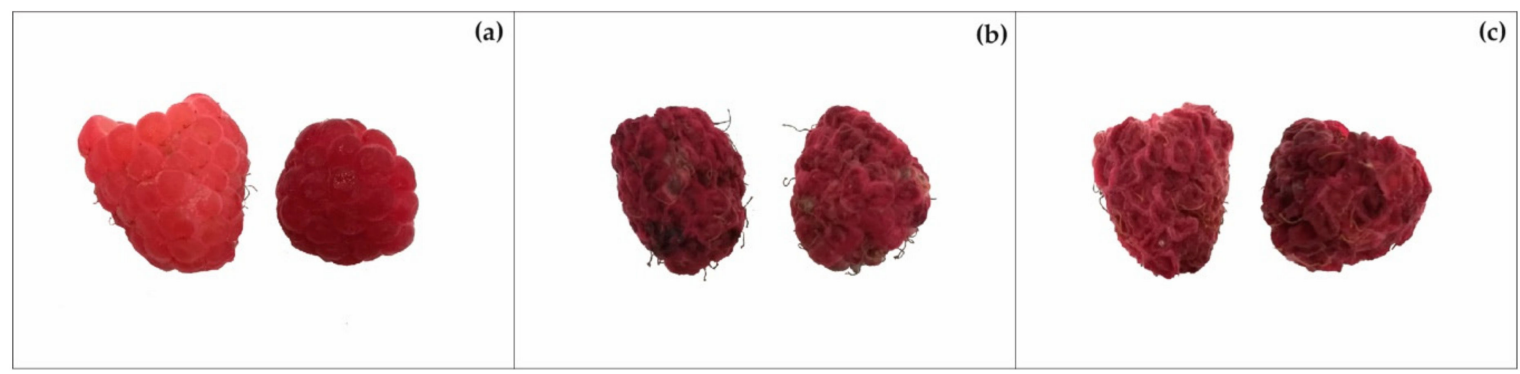

Figure 2. Fresh raspberries (a), $\sim 80 \%$ moisture. Conventional hot air-dried raspberries (b), $\sim 4 \%$ moisture. Heat pump-dried raspberries (c), $\sim 14 \%$ moisture.

In view of the above, the use of heat pump-drying technology for the postharvest processing of raspberry fruit may allow slightly greater retention of some bioactive compounds with respect to conventional hot air drying. In addition to the benefits derived for human health, heat pump-drying technology also allows the reduction of energy consumption for processing [80].

\section{Conclusions}

The attention of the food industry on the preservation and improvement of the qualities of processed berries has progressively increased, with the goal of finding critical points during the postharvest processes of raspberry that affect final product quality. The storage and processing technologies of red raspberries reviewed here showed different influences specific to each processing technique on the final bioactive chemical compound content. The content of bioactive chemical compounds is relatively stable during storage, with some minor changes in ascorbic acid or anthocyanin content during cold (at $5{ }^{\circ} \mathrm{C}$ ) or frozen storage.

Among drying techniques, the freeze-drying method is most likely the best processing method for retaining the content of bioactive chemical compounds, but it requires high costs for the implementation of a large-scale production of dried berries. The conventional hot air-drying method, which is the most used by the food industry, is most likely the worst drying method for bioactive chemical compound retention (especially anthocyanins and ascorbic acid).

New technologies, such as microwave- and heat pump-drying, which are cheaper than conventional methods, are emerging as promising processes to provide a higher retention of bioactive chemical compounds in dried berries. However, changes in quantity and the profile of bioactive chemical compounds in raspberry fruit subjected to these different postharvest drying processes need further investigation. In this way, the future research on this topic should be in-depth analyses at the molecular level, using different drying times, temperatures and also new possible combinations between different drying techniques (e.g., heat pump and microwave). These studies will provide useful indicators for developing new industrial processing methods.

Author Contributions: Conceived and designed the experiments, R.M., and L.G.; performed the experiments, analysed data and wrote the manuscript, E.L.P., D.R. and L.M.G.; reviewed and edited the paper, M.L., L.G., R.M. and D.R. All authors have read and agreed to the published version of the manuscript.

Funding: This research was performed in the framework of 'Erbi Boni' project, funded by FEASR Reg. UE 1305/2013-PSR 2014/2020—Regione Toscana Mis. 19-GAL MontagnAppennino Mis. 16.2.

Acknowledgments: Authors are grateful to Franca Bernardi for the technical support and Matteo Guidi, who provided us with wild raspberries.

Conflicts of Interest: The authors declare no conflict of interest. 


\section{References}

1. Patel, A.; Rojas-Vera, J.; Dacke, C. Therapeutic constituents and actions of Rubus species. Curr. Med. Chem. 2004, 11, 1501-1512. [CrossRef] [PubMed]

2. Rao, A.V.; Snyder, D.M. Raspberries and human health: A review. J. Agric. Food Chem. 2010, 58, 3871-3883. [CrossRef] [PubMed]

3. Graham, J.; Brennan, R. Raspberry: Breeding, Challenges and Advances; Springer International Publishing: Cham, Switzerland, 2018; ISBN 978-3-319-99030-9.

4. De Souza, V.R.; Pereira, P.A.P.; da Silva, T.L.T.; de Oliveira Lima, L.C.; Pio, R.; Queiroz, F. Determination of the bioactive compounds, antioxidant activity and chemical composition of Brazilian blackberry, red raspberry, strawberry, blueberry and sweet cherry fruits. Food Chem. 2014, 156, 362-368. [CrossRef] [PubMed]

5. Basu, A.; Rhone, M.; Lyons, T.J. Berries: Emerging impact on cardiovascular health. Nutr. Rev. 2010, 68, 168-177. [CrossRef]

6. Pantelidis, G.; Vasilakakis, M.; Manganaris, G.; Diamantidis, G. Antioxidant capacity, phenol, anthocyanin and ascorbic acid contents in raspberries, blackberries, red currants, gooseberries and Cornelian cherries. Food Chem. 2007, 102, 777-783. [CrossRef]

7. Yang, J.; Cui, J.; Chen, J.; Yao, J.; Hao, Y.; Fan, Y.; Liu, Y. Evaluation of physicochemical properties in three raspberries (Rubus idaeus) at five ripening stages in northern China. Sci. Hortic. 2020, 263, 109146. [CrossRef]

8. Tosun, M.; Ercisli, S.; Karlidag, H.; Sengul, M. Characterization of red raspberry (Rubus idaeus L.) genotypes for their physicochemical properties. J. Food Sci. 2009, 74, C575-C579. [CrossRef]

9. Mazur, S.P.; Nes, A.; Wold, A.B.; Remberg, S.F.; Aaby, K. Quality and chemical composition of ten red raspberry (Rubus idaeus L.) genotypes during three harvest seasons. Food Chem. 2014, 160, 233-240. [CrossRef]

10. Neveu, V.; Perez-Jimenez, J.; Vos, F.; Crespy, V.; du Chaffaut, L.; Mennen, L.; Knox, C.; Eisner, R.; Cruz, J.; Wishart, D.; et al. Phenol-Explorer: An online comprehensive database on polyphenol contents in foods. Database 2010, 2010, bap024. [CrossRef]

11. Sivakumaran, S.; Huffman, L.; Sivakumaran, S.; Drummond, L. The nutritional composition of Zespri ${ }^{\circledR}$ SunGold kiwifruit and Zespri ${ }^{\circledR}$ Sweet Green kiwifruit. Food Chem. 2018, 238, 195-202. [CrossRef]

12. Lee, H.S.; Coates, G.A. Vitamin C in frozen, fresh squeezed, unpasteurized, polyethylene-bottled orange juice: A storage study. Food Chem. 1999, 65, 165-168. [CrossRef]

13. Statistics Division FAOSTAT_Food and Agriculture Organization of the United Nations. Available online: http://www.fao.org/faostat/en/\#home (accessed on 1 July 2020).

14. FAO. Global Food Losses and Food Waste_Extent, Causes and Prevention; FAO: Rome, Italy, 2011.

15. Haffner, K.; Rosenfeld, H.J.; Skrede, G.; Wang, L. Quality of red raspberry Rubus idaeus L. cultivars after storage in controlled and normal atmospheres. Postharvest Biol. Technol. 2002, 24, 279-289. [CrossRef]

16. Forney, C.F.; Jamieson, A.R.; Munro Pennell, K.D.; Jordan, M.A.; Fillmore, S.A.E. Relationships between fruit composition and storage life in air or controlled atmosphere of red raspberry. Postharvest Biol. Technol. 2015, 110, 121-130. [CrossRef]

17. Callesen, O.; Holm, B. Storage results with red raspberry. Acta Hortic. 1989, 247-254. [CrossRef]

18. Sablani, S.S.; Andrews, P.K.; Davies, N.M.; Walters, T.; Saez, H.; Bastarrachea, L. Effects of air and freeze drying on phytochemical content of conventional and organic berries. Dry. Technol. 2011, 29, 205-216. [CrossRef]

19. Si, X.; Chen, Q.; Bi, J.; Wu, X.; Yi, J.; Zhou, L.; Li, Z. Comparison of different drying methods on the physical properties, bioactive compounds and antioxidant activity of raspberry powders: Effect of drying method on properties of raspberry powders. J. Sci. Food Agric. 2016, 96, 2055-2062. [CrossRef]

20. Mejia-Meza, E.I.; Yanez, J.A.; Remsberg, C.M.; Takemoto, J.K.; Davies, N.M.; Rasco, B.; Clary, C. Effect of dehydration on raspberries: Polyphenol and anthocyanin retention, antioxidant capacity, and antiadipogenic activity. J. Food Sci. 2010, 75, H5-H12. [CrossRef]

21. Sadowska, K.; Andrzejewska, J.; Klóska, Ł. Influence of freezing, lyophilisation and air-drying on the total monomeric anthocyanins, vitamin C and antioxidant capacity of selected berries. Int. J. Food Sci. Technol. 2017, 52, 1246-1251. [CrossRef]

22. Bermúdez-Soto, M.J.; Tomás-Barberán, F.A. Evaluation of commercial red fruit juice concentrates as ingredients for antioxidant functional juices. Eur. Food Res. Technol. 2004, 219, 133-141. [CrossRef] 
23. Bustos, M.C.; Rocha-Parra, D.; Sampedro, I.; de Pascual-Teresa, S.; León, A.E. The influence of different air-drying conditions on bioactive compounds and antioxidant activity of berries. J. Agric. Food Chem. 2018, 66, 2714-2723. [CrossRef]

24. Weber, F.; Larsen, L.R. Influence of fruit juice processing on anthocyanin stability. Food Res. Int. 2017, 100, 354-365. [CrossRef]

25. Michalska, A.; Łysiak, G. Bioactive compounds of blueberries: Postharvest factors influencing the nutritional value of products. Int. J. Mol. Sci. 2015, 16, 18642-18663. [CrossRef] [PubMed]

26. Furtado, P.; Figueiredo, P.; Chaves das Neves, H.; Pina, F. Photochemical and thermal degradation of anthocyanidins. J. Photochem. Photobiol. Chem. 1993, 75, 113-118. [CrossRef]

27. Patras, A.; Brunton, N.P.; O’Donnell, C.; Tiwari, B.K. Effect of thermal processing on anthocyanin stability in foods; mechanisms and kinetics of degradation. Trends Food Sci. Technol. 2010, 21, 3-11. [CrossRef]

28. Hamadziripi, E.T.; Theron, K.I.; Muller, M.; Steyn, W.J. Apple compositional and peel color differences resulting from canopy microclimate affect consumer preference for eating quality and appearance. HortScience 2014, 49, 384-392. [CrossRef]

29. Lee, S.M.; Lee, K.T.; Lee, S.H.; Song, J.K. Origin of human colour preference for food. J. Food Eng. 2013, 119, 508-515. [CrossRef]

30. Prokop, P.; Fančovičová, J. Beautiful fruits taste good: The aesthetic influences of fruit preferences in humans. Anthropol. Anz. 2012, 69, 71-83. [CrossRef]

31. Pritts, M.P. Raspberries and related fruits. In Encyclopedia of Food Sciences and Nutrition, 2nd ed.; Caballero, B., Ed.; Elsevier: Amsterdam, The Netherlands, 2003; pp. 4916-4921. ISBN 978-0-12-227055-0.

32. Krüger, E.; Dietrich, H.; Schöpplein, E.; Rasim, S.; Kürbel, P. Cultivar, storage conditions and ripening effects on physical and chemical qualities of red raspberry fruit. Postharvest Biol. Technol. 2011, 60, 31-37. [CrossRef]

33. Oduse, K.A.; Cullen, D. An investigation into the fruit firmness properties of some progeny and cultivars of red raspberry (Rubus idaeus). J. Environ. Sci. Toxicol. Food Technol. 2012, 1, 4-12. [CrossRef]

34. Zhang, D.; Quantick, P.C. Antifungal effects of chitosan coating on fresh strawberries and raspberries during storage. J. Hortic. Sci. Biotechnol. 1998, 73, 763-767. [CrossRef]

35. Giuffrè, A.M.; Louadj, L.; Rizzo, P.; De Salvo, E.; Sicari, V. The Influence of film and storage on the phenolic and antioxidant properties of red raspberries (Rubus idaeus L.) cv. Erika. Antioxidants 2019, 8, 254. [CrossRef] [PubMed]

36. Cortellino, G.; De Vecchi, P.; Lo Scalzo, R.; Ughini, V.; Granelli, G.; Buccheri, M. Ready-to-eat raspberries: Qualitative and nutraceutical characteristics during shelf-life. Adv. Hortic. Sci. 2018, 399-406. [CrossRef]

37. Mullen, W.; Stewart, A.J.; Lean, M.E.J.; Gardner, P.; Duthie, G.G.; Crozier, A. Effect of freezing and storage on the phenolics, ellagitannins, flavonoids, and antioxidant capacity of red raspberries. J. Agric. Food Chem. 2002, 50, 5197-5201. [CrossRef] [PubMed]

38. Giovanelli, G.; Limbo, S.; Buratti, S. Effects of new packaging solutions on physico-chemical, nutritional and aromatic characteristics of red raspberries (Rubus idaeus L.) in postharvest storage. Postharvest Biol. Technol. 2014, 98, 72-81. [CrossRef]

39. Stavang, J.A.; Freitag, S.; Foito, A.; Verrall, S.; Heide, O.M.; Stewart, D.; Sønsteby, A. Raspberry fruit quality changes during ripening and storage as assessed by colour, sensory evaluation and chemical analyses. Sci. Hortic. 2015, 195, 216-225. [CrossRef]

40. Kalt, W.; Forney, C.F.; Martin, A.; Prior, R.L. Antioxidant capacity, vitamin C, phenolics, and anthocyanins after fresh storage of small fruits. J. Agric. Food Chem. 1999, 47, 4638-4644. [CrossRef]

41. Ali, L.; Svensson, B.; Alsanius, B.W.; Olsson, M.E. Late season harvest and storage of Rubus berries-Major antioxidant and sugar levels. Sci. Hortic. 2011, 129, 376-381. [CrossRef]

42. Dziedzic, E.; Błaszczyk, J.; Bieniasz, M.; Dziadek, K.; Kopeć, A. Effect of modified (MAP) and controlled atmosphere (CA) storage on the quality and bioactive compounds of blue honeysuckle fruits (Lonicera caerulea L.). Sci. Hortic. 2020, 265, 109226. [CrossRef]

43. Yang, M.; Ban, Z.; Luo, Z.; Li, J.; Lu, H.; Li, D.; Chen, C.; Li, L. Impact of elevated $\mathrm{O}_{2}$ and $\mathrm{CO}_{2}$ atmospheres on chemical attributes and quality of strawberry (Fragaria $\times$ ananassa Duch.) during storage. Food Chem. 2020, 307, 125550. [CrossRef]

44. Agar, I.T.; Streif, J.; Bangerth, F. Effect of high $\mathrm{CO}_{2}$ and controlled atmosphere (CA) on the ascorbic and dehydroascorbic acid content of some berry fruits. Postharvest Biol. Technol. 1997, 11, 47-55. [CrossRef] 
45. González-Orozco, B.D.; Mercado-Silva, E.M.; Castaño-Tostado, E.; Vázquez-Barrios, M.E.; Rivera-Pastrana, D.M. Effect of short-term controlled atmospheres on the postharvest quality and sensory shelf life of red raspberry (Rubus idaeus L.). CyTA-J. Food 2020, 18, 352-358. [CrossRef]

46. De Ancos, B.; González, E.M.; Cano, M.P. Ellagic acid, vitamin C, and total phenolic contents and radical scavenging capacity affected by freezing and frozen storage in raspberry fruit. J. Agric. Food Chem. 2000, 48, 4565-4570. [CrossRef] [PubMed]

47. Türkben, C.; Sarıburun, E.; Demir, C.; Uylaşer, V. Effect of freezing and frozen storage on phenolic compounds of raspberry and blackberry cultivars. Food Anal. Methods 2010, 3, 144-153. [CrossRef]

48. Häkkinen, S.H.; Kärenlampi, S.O.; Mykkänen, H.M.; Heinonen, I.M.; Törrönen, A.R. Ellagic acid content in berries: Influence of domestic processing and storage. Eur. Food Res. Technol. 2000, 212, 75-80. [CrossRef]

49. Šamec, D.; Piljac-Žegarac, J. Fluctuations in the levels of antioxidant compounds and antioxidant capacity of ten small fruits during one year of frozen storage. Int. J. Food Prop. 2015, 18, 21-32. [CrossRef]

50. Bobinalt, R.; Viškelis, P. Quality of Raspberry Fruits after Frozen Storage. In Proceedings of the 5th International Technical Symposium on Food Processing, Monitoring Technology in Bioprocesses and Food Quality Management, Postdam, Germany, 31 August-2 September 2009.

51. De Ancos, B.; Ibañez, E.; Reglero, G.; Cano, M.P. Frozen storage effects on anthocyanins and volatile compounds of raspberry fruit. J. Agric. Food Chem. 2000, 48, 873-879. [CrossRef]

52. Rommel, A.; Heatherbell, D.A.; Wrolstad, R.E. Red raspberry juice and wine: Effect of processing and storage on anthocyanin pigment composition, color and appearance. J. Food Sci. 1990, 55, 1011-1017. [CrossRef]

53. Boyles, M.J.; Wrolstad, R.E. Anthocyanin composition of red raspberry juice: Influences of cultivar, processing, and environmental factors. J. Food Sci. 1993, 58, 1135-1141. [CrossRef]

54. Reque, P.M.; Steffens, R.S.; Jablonski, A.; Flôres, S.H.; Rios, A.D.O.; de Jong, E.V. Cold storage of blueberry (Vaccinium spp.) fruits and juice: Anthocyanin stability and antioxidant activity. J. Food Compos. Anal. 2014, 33, 111-116. [CrossRef]

55. Piljac-Žegarac, J.; Šamec, D. Antioxidant stability of small fruits in postharvest storage at room and refrigerator temperatures. Food Res. Int. 2011, 44, 345-350. [CrossRef]

56. Allan, A.C.; Espley, R.V. MYBs drive novel consumer traits in fruits and vegetables. Trends Plant Sci. 2018, 23, 693-705. [CrossRef] [PubMed]

57. Espley, R.V.; Bovy, A.; Bava, C.; Jaeger, S.R.; Tomes, S.; Norling, C.; Crawford, J.; Rowan, D.; McGhie, T.K.; Brendolise, C.; et al. Analysis of genetically modified red-fleshed apples reveals effects on growth and consumer attributes. Plant Biotechnol. J. 2013, 11, 408-419. [CrossRef] [PubMed]

58. Sójka, M.; Macierzyński, J.; Zaweracz, W.; Buczek, M. Transfer and mass balance of ellagitannins, anthocyanins, flavan-3-ols, and flavonols during the processing of red raspberries (Rubus idaeus L.) to juice. J. Agric. Food Chem. 2016, 64, 5549-5563. [CrossRef] [PubMed]

59. Sablani, S.S.; Andrews, P.K.; Davies, N.M.; Walters, T.; Saez, H.; Syamaladevi, R.M.; Mohekar, P.R. Effect of thermal treatments on phytochemicals in conventionally and organically grown berries: Effect of thermal treatments on phytochemicals in berries. J. Sci. Food Agric. 2010, 90, 769-778. [CrossRef]

60. Jiménez-Sánchez, C.; Lozano-Sánchez, J.; Segura-Carretero, A.; Fernández-Gutiérrez, A. Alternatives to conventional thermal treatments in fruit-juice processing. Part 1: Techniques and applications. Crit. Rev. Food Sci. Nutr. 2017, 57, 501-523. [CrossRef]

61. Kamiloglu, S.; Toydemir, G.; Boyacioglu, D.; Beekwilder, J.; Hall, R.D.; Capanoglu, E. A Review on the effect of drying on antioxidant potential of fruits and vegetables. Crit. Rev. Food Sci. Nutr. 2016, 56, S110-S129. [CrossRef]

62. Ratti, C. Hot air and freeze-drying of high-value foods: A review. J. Food Eng. 2001, 49, 311-319. [CrossRef]

63. Novaković, M.M.; Stevanović, S.M.; Gorjanović, S.Ž.; Jovanovic, P.M.; Tešević, V.V.; Janković, M.A.; Sužnjević, D.Ž. Changes of hydrogen peroxide and radical-scavenging activity of raspberry during osmotic, convective, and freeze-drying. J. Food Sci. 2011, 76, C663-C668. [CrossRef]

64. Stamenković, Z.; Pavkov, I.; Radojčin, M.; Tepić Horecki, A.; Kešelj, K.; Bursać Kovačević, D.; Putnik, P. Convective drying of fresh and frozen raspberries and change of their physical and nutritive properties. Foods 2019, 8, 251. [CrossRef]

65. Harguindeguy, M.; Fissore, D. On the effects of freeze-drying processes on the nutritional properties of foodstuff: A review. Dry. Technol. 2020, 38, 846-868. [CrossRef] 
66. Tomás-Barberán, F.A.; Espín, J.C. Phenolic compounds and related enzymes as determinants of quality in fruits and vegetables: Phenolics and food quality. J. Sci. Food Agric. 2001, 81, 853-876. [CrossRef]

67. Caritá, A.C.; Fonseca-Santos, B.; Shultz, J.D.; Michniak-Kohn, B.; Chorilli, M.; Leonardi, G.R. Vitamin C: One compound, several uses. Advances for delivery, efficiency and stability. Nanomedicine Nanotechnol. Biol. Med. 2020, 24, 102117. [CrossRef] [PubMed]

68. Goula, A.M.; Adamopoulos, K.G. Retention of ascorbic acid during drying of tomato halves and tomato pulp. Dry. Technol. 2006, 24, 57-64. [CrossRef]

69. Rodriguez, A.; Rodriguez, M.M.; Lemoine, M.L.; Mascheroni, R.H. Study and comparison of different drying processes for dehydration of raspberries. Dry. Technol. 2017, 35, 689-698. [CrossRef]

70. Rodriguez, A.; Bruno, E.; Paola, C.; Campañone, L.; Mascheroni, R.H. Experimental study of dehydration processes of raspberries (Rubus Idaeus) with microwave and solar drying. Food Sci. Technol. 2019, 39, 336-343. [CrossRef]

71. Li, F.; Chen, G.; Zhang, B.; Fu, X. Current applications and new opportunities for the thermal and non-thermal processing technologies to generate berry product or extracts with high nutraceutical contents. Food Res. Int. 2017, 100, 19-30. [CrossRef]

72. Perera, C.O.; Rahman, M.S. Heat pump dehumidifier drying of food. Trends Food Sci. Technol. 1997, 8, 75-79. [CrossRef]

73. Ong, S.P.; Law, C.L. Drying kinetics and antioxidant phytochemicals retention of salak fruit under different drying and pretreatment conditions. Dry. Technol. 2011, 29, 429-441. [CrossRef]

74. Maillard, M.-N.; Berset, C. Evolution of antioxidant activity during kilning: Role of insoluble bound phenolic acids of barley and malt. J. Agric. Food Chem. 1995, 43, 1789-1793. [CrossRef]

75. Dalmadi, I.; Rapeanu, G.; Van Loey, A.; Smout, C.; Hendrickx, M. Characterization and inactivation by thermal and pressure processing of strawberry (Fragaria $\times$ ananassa) polyphenol oxidase: A kinetic study. $J$. Food Biochem. 2006, 30, 56-76. [CrossRef]

76. Queiroz, C.; Mendes Lopes, M.L.; Fialho, E.; Valente-Mesquita, V.L. Polyphenol oxidase: Characteristics and mechanisms of browning control. Food Rev. Int. 2008, 24, 361-375. [CrossRef]

77. Beekwilder, J.; Jonker, H.; Meesters, P.; Hall, R.D.; van der Meer, I.M.; Ric de Vos, C.H. Antioxidants in raspberry: On-Line analysis links antioxidant activity to a diversity of individual metabolites. J. Agric. Food Chem. 2005, 53, 3313-3320. [CrossRef] [PubMed]

78. Taşeri, L.; Aktaş, M.; Şevik, S.; Gülcü, M.; Uysal Seçkin, G.; Aktekeli, B. Determination of drying kinetics and quality parameters of grape pomace dried with a heat pump dryer. Food Chem. 2018, 260, 152-159. [CrossRef] [PubMed]

79. Lo Piccolo, E.; Landi, M.; Massai, R.; Remorini, D.; Guidi, L. Girled-induced anthocyanin accumulation in red-leafed Prunus cerasifera: Effect on photosynthesis, photoprotection and sugar metabolism. Plant Sci. 2020, 294, 110456. [CrossRef] [PubMed]

80. Ceccanti, C.; Landi, M.; Antichi, D.; Guidi, L.; Manfrini, L.; Monti, M.; Tosti, G.; Frasconi, C. Bioactive Properties of fruits and leafy vegetables managed with integrated, organic, and organic no-tillage practices in the Mediterranean area: A two-year rotation experiment. Agronomy 2020, 10, 841. [CrossRef]

Publisher's Note: MDPI stays neutral with regard to jurisdictional claims in published maps and institutional affiliations.

(C) 2020 by the authors. Licensee MDPI, Basel, Switzerland. This article is an open access article distributed under the terms and conditions of the Creative Commons Attribution (CC BY) license (http://creativecommons.org/licenses/by/4.0/). 